\title{
European continuous active tectonic strain-stress map
}

\author{
A.J. Olaiz ${ }^{\text {a }}$, A. Muñoz-Martín ${ }^{\text {a,* }}$, G. De Vicente ${ }^{\text {a }}$, R. Vegas ${ }^{\text {a }}$, S. Cloetingh ${ }^{\text {b }}$ \\ a G.I. Tectonofisica Aplicada, Dpto. Geodinámica, Univ. Complutense de Madrid, Universidad Complutense de Madrid, 28040 Madrid, Spain \\ ${ }^{\mathrm{b}}$ Faculty of Earth and Life Sciences, Vrije Universiteit Amsterdam, The Netherlands
}

\section{A R T I C L E I N F O}

\section{Article history:}

Received 6 February 2008

Received in revised form 17 June 2008

Accepted 27 June 2008

Available online $\mathrm{xxxx}$

\section{Keywords:}

Active strain-stress

Focal mechanism

Centroid moment inversion

Europe

\begin{abstract}
A B S T R A C T
This paper shows a new continuous strain-stress map for Europe obtained from the direct inversion of earthquake focal mechanisms calculated from the centroid tensor method. A total of 1608 focal mechanisms have been selected with several quality criteria from different catalogues (CMT Harvard, ETH, Med-Net, I.G.N. and I.A.G.) from 1973 to the present day. Values for the maximum horizontal shortening direction and brittle strain-stress regime defined by the $k^{\prime}$ ratio $\left(e_{\mathrm{y}} / e_{\mathrm{z}}\right.$, horizontal maximum/vertical strain) have been calculated following in Europe and Pannonian Basin the slip model of tri-axial deformation. The individual results including Dey and the shape of the active brittle strain ellipsoid have been interpolated to a final $15^{\prime}$ regular grid taking into account the relationship between the tectonic horizontal strain-stress value and the vertical load. Both continuous strain regime and maximum horizontal shortening (Dey) maps show a good correlation with the primary tectonic forces generated along the plate boundaries, plate kinematics and also some local perturbations related with main crustal heterogeneities and topography, as well as significant spatial variations in integrated crustal strength.
\end{abstract}

\section{Introduction}

During the last two decades, numerous studies have been conducted to determine the active strain-stress field in the Western Eurasian Plate. Among these studies, the World Stress Map Project (WSMP, Zoback, 1992) provides a general overview of neotectonics and present-day stress fields, with a database available to the academic community and society as a whole (Reinecker et al., 2005). The present-day stress field, exerting a major on active deformation in the lithosphere, is a key in constraining numerical and analogue models for the quantification of active tectonic processes.

The WSMP shows regionally uniform stress orientations and magnitudes, and global (Zoback, 1992) and European first, (Müller et al., 1992) second and third-order stress provinces have been mapped (Heidbach et al., 2007). The continuous increase in the amount of stress indicators improved the resolution at low-scales, allowing recognition of local changes in the stress regime and Shmax orientations (Rebaï et al., 1992).

The WSMP database, as well as other studies, have shown that Western Eurasia (Europe and the surrounding Mediterranean zones) represents a region of complex contemporaneous stress pattern (Figs. 1 and 2). The Shmax orientations are the result of the tectonic primary forces: North-Atlantic Ridge push, and collisional forces generated along the southern convergent European limit (Zoback, 1992; Grünthal and Stromeyer, 1992; Müller et al., 1992). More recently, numerical models have been constructed taking into account

\footnotetext{
* Corresponding author.

E-mail address: amunoz@geo.ucm.es (A. Muñoz-Martín).
}

other tectonic constraints that may be important in the generation of intraplate stresses, like lateral density variations in the lithosphere and topography (Gölke and Coblentz, 1996; Andeweg et al., 1998). These models obtain more realistic results on a global scale. Local stress studies focus on the structural control of local stress fields controlled by the presence of inherited crustal heterogeneities and tectonic inversion processes (Angelier, 1990; Carey and Mercier, 1992; De Vicente et al., 2008; IPSN, 1993; Plenefisch and Bonjer, 1997; CSN, 1998).

Nevertheless, heterogeneous data distribution provides a major limitation in calculating stress maps. This can be critical, especially in zones of low to moderate instrumental seismicity, as most parts of intraplate domains, making it very difficult to draw continuous strainstress maps as a result of the low data density (Bada et al., 2007). In these circumstances, the application of the "Slip Model of tri-axial deformation" proposed by Reches (1983) following the methodology developed by De Vicente (1988) allows the orientation of maximum and minimum horizontal stresses to be calculated as well as the shape factor $\left(k^{\prime}\right)$ for each individual focal mechanism. This procedure has been successfully used in the zone between the Mid Atlantic Ridge and Algeria, both from first P-arrivals (Herraiz et al., 2000) and moment tensor focal mechanisms (De Vicente et al., 2008).

The main purpose of this paper is to present a new continuous active strain-stress map for Europe and the Mediterranean using earthquake focal mechanisms calculated from the centroid moment tensor inversion (Dziewonski et al., 1982). Fracturing-faulting is the process that generates tectonic earthquakes, recognised to be a scaleinvariant dynamics, to characterize the active strain-stress state of an area. It is, therefore, possible to use different earthquake magnitudes if 


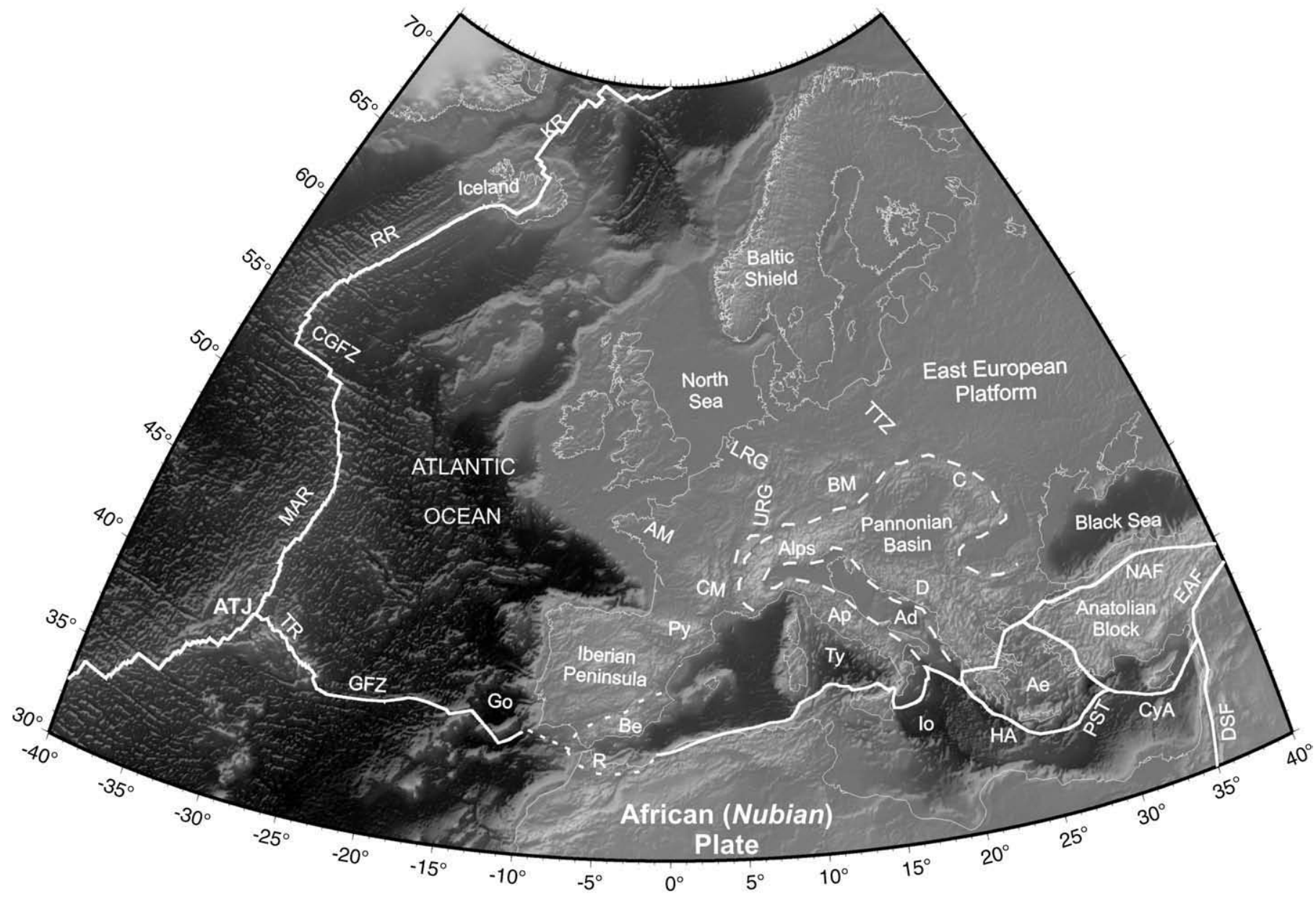

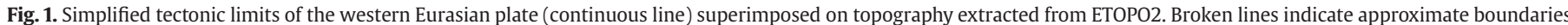

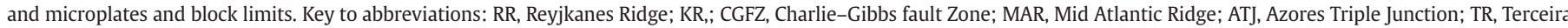

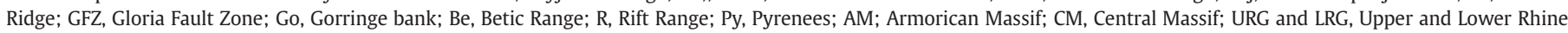

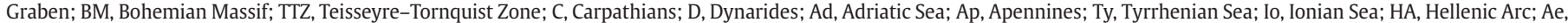
Aegean Sea; CyA, Cyprus Arc; PST, Plinio-Strabo Trenches; DSF, Dead Sea Fault zone; NAF and EAF, North and East Anatolian Faults.

they have been determined with good quality (depending also on the density of the seismic network). In our case, we have only used focal mechanisms calculated with the centroid moment tensor method, whose data sources and characteristics are much more homogeneous than those calculated from first P-wave arrivals, described below. It is a much more restrictive procedure and provides much better results (De Vicente et al., 2008). Actually, there are sufficient data to apply this kind of analysis to the European scale (Fig. 2). Finally, we will discuss some pertinent aspects of the strain-stress maps obtained from a tectonic plate-scale perspective.

\section{Data sources}

The studies of active stresses are normally carried out by using different types of indicators: earthquake focal mechanisms, borehole breakouts and geological fault-slip data, the first-mentioned being the ones which are most used. The slip direction on a fault plane during an earthquake becomes conditioned by the stress tensor at the source location. So, earthquakes sample the present-day tectonic stress field over the entire thickness of the seismogenic layer. Therefore, earthquake focal mechanisms are valuable and widely-used stress indicators. With the densification of the seismic broadband networks in recent years, regional moment tensor inversion has become an important source of homogeneous wide-scale stress indicators (Pondrelli et al., 2002, 2004; Braunmiller et al., 2002; Stich et al.,
2003; Rueda and Mezcua, 2005). These national and European moment tensor networks invert three-component time domain displacement seismograms, including P-, S- and surface waves, for the mechanical force system associated with earthquake slip, thereby combining a far more complete evaluation of the recorded wavefield with a more general parameterization of the seismic source. The consideration of the full phase and amplitude information of several wave groups helps to constrain the source orientation, and moment tensor solutions can be obtained from relatively few regional recordings (Dreger and Helmberger, 1993; Randall et al., 1995). In this way, moment tensor inversion can be applied to a relevant number of events, contributing to a better spatial sampling and larger populations of focal mechanisms. Simultaneously, full waveform inversion can overcome ambiguities in traditional first motion solutions.

Moment tensor solutions for the western Eurasia-Mediterranean area are available from several routine moment tensor projects: The global Harvard centroid moment tensor (CMT) catalogue (Dziewonski and Woodhouse, 1983) contains events larger than magnitude $~ 5.5$ since 1977; this catalogue contributes solutions mainly in northern Algeria and in the Atlantic, where moderate to large earthquakes occur with certain frequency. Moment tensor projects at the EuroMediterranean scale are the Italian INGV (Pondrelli et al., 2002, 2004) and the ETH-Zürich (Braunmiller et al., 2002). They can include additional moderate earthquakes larger than magnitude $\sim 4$, since the 


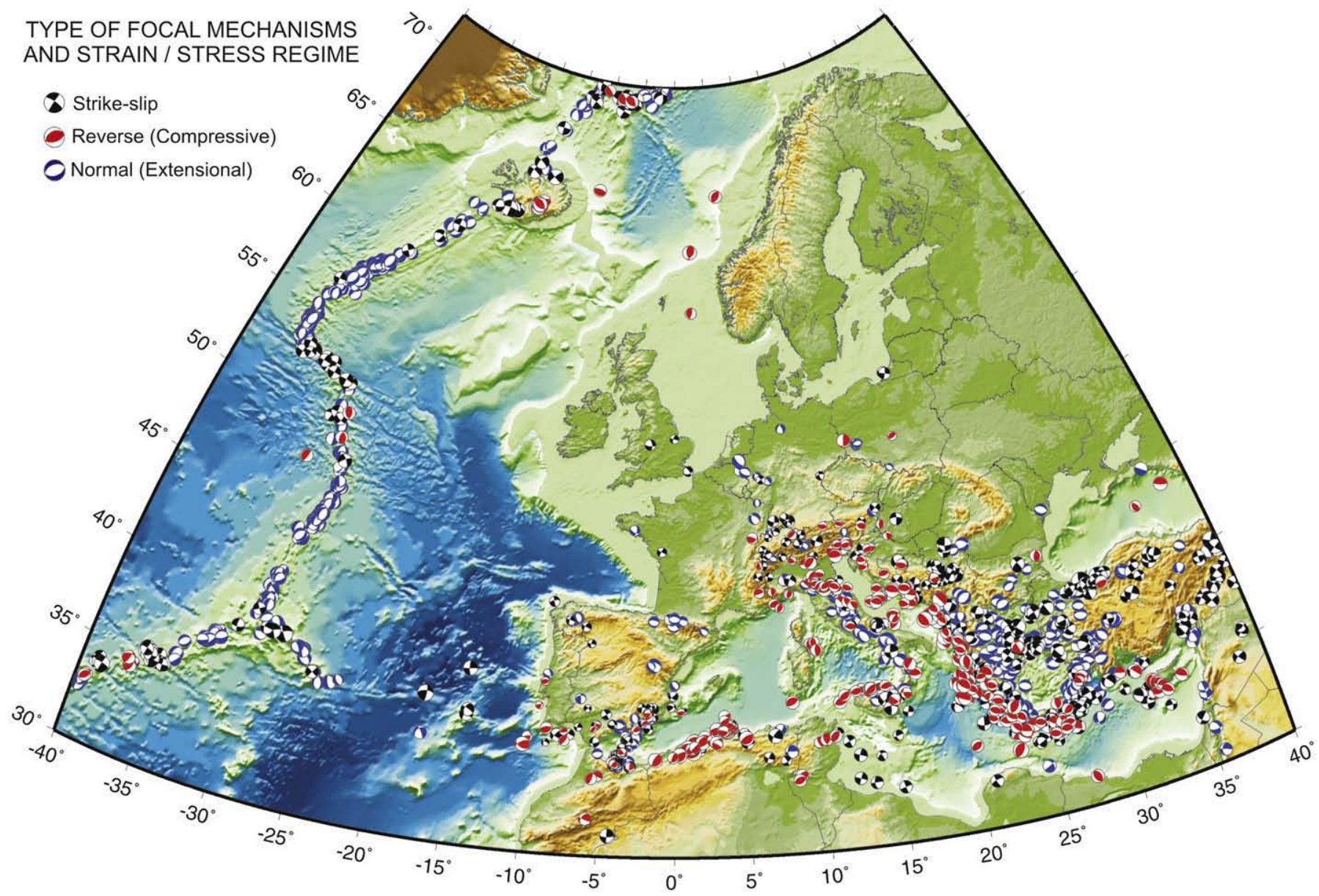

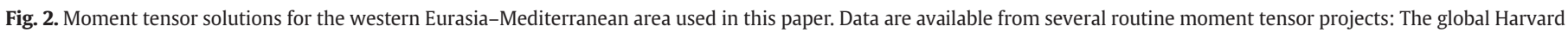

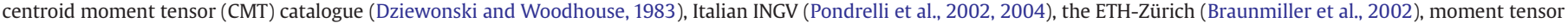
project at IAG-Granada (Stich et al., 2003) and IGN-Madrid (Rueda and Mezcua, 2005). The final database contains 1608 earthquakes with Mw values between 2.6 and 7.5.

shorter average event-station paths permit an appropriate correction of propagation effects for the intermediate-period wavefield from available, simplified earth models. The Ibero-Maghrebian moment tensor project at IAG-Granada (Stich et al., 2003) inverts earthquakes larger than 3.5 from a dense station network and provides the currently largest moment tensor inventory for the region. Finally, in 2003, IGN-Madrid started operating fully automated near-real time inversion, based on the 3 closest regional recordings for earthquakes larger than magnitude 3.3 (Rueda and Mezcua, 2005).

In this paper we have merged these catalogues to build up a moment tensor inventory for the western Eurasia-Mediterranean zone. When there are multiple solutions for the same event, we selected the solution with the lowest percentage of non-doublecouple (CLVD) components of the moment tensors (Dziewonski and Woodhouse, 1983), also taking into account the station coverage involved in the different inversions. Our merged moment tensor list for regional stress field analysis contains events between $\mathrm{N} 72^{\circ}$ and $\mathrm{N} 30^{\circ}$ latitude and $40^{\circ} \mathrm{W}-40^{\circ} \mathrm{E}$ longitude. As the main objective was to constrain the crustal (and uppermost mantle) stress field, we have only considered earthquakes with a hypocentral depth less than $70 \mathrm{~km}$ (1680 focal mechanisms). The solutions obtained from this database will be analysed to contrast with previous results obtained from simply mapping $\mathrm{P}$ axis of focal mechanisms, and to interpret large scale active tectonics where data density permits a good resolution of regional strain-stress conditions. The final database used for the construction of these maps is plotted in Fig. 2 and contains 1608 earthquakes with Mw values between 2.6 and 7.5 .

\section{Methodology}

For the calculation of the orientation and the shape factor of the strain-stress ellipsoid we have applied the methodology proposed by De Vicente (1988), based on the "slip model of tri-axial deformation" (Reches, 1983). This method assumes two important restrictions: 1) The main axes of brittle deformation (strain) and the principal stresses are parallel, and 2) One of the strain-stress axes is vertical. Even

Table 1

$k^{\prime}$ parameter $\left(e_{\mathrm{y}} / e_{\mathrm{z}}\right)$ and normalized $k^{\prime}$ values for the different strain regimes and number of focal mechanism used in this work

\begin{tabular}{|c|c|c|c|}
\hline $\begin{array}{l}k^{\prime} \text { value } \\
\left(e_{\mathrm{y}} / e_{\mathrm{z}}\right)\end{array}$ & $\begin{array}{l}\text { Normalized } k^{\prime} \\
\text { value (NK) }\end{array}$ & $\begin{array}{l}\text { Strain } \\
\text { regime }\end{array}$ & $\begin{array}{l}\text { Focal } \\
\text { mechanisms }\end{array}$ \\
\hline$-0.5 \leq k^{\prime} \leq 0.1$ & $\begin{array}{l}0 \leq \mathrm{NK} \leq 10 \\
\mathrm{NK}=k^{\prime} \cdot 100\end{array}$ & Uniaxial extension & $496(31 \%)$ \\
\hline $0.1 \leq k^{\prime} \leq 1$ & $\begin{array}{l}10 \leq \mathrm{NK} \leq 100 \\
\mathrm{NK}=k^{\prime} \cdot 100\end{array}$ & Extensive / strike-slip & $244(15 \%)$ \\
\hline $1 \leq k^{\prime} \leq 10$ & $\begin{array}{l}100 \leq \mathrm{NK} \leq 106 \\
\mathrm{NK}=1.11 \cdot k+98.9\end{array}$ & Strike-slip / extensive & $218(14 \%)$ \\
\hline $\begin{array}{l}k^{\prime} \leq-10 \\
k^{\prime} \geq+10\end{array}$ & $\begin{array}{l}\mathrm{NK}=0.4 \cdot k^{\prime}+194 \\
\mathrm{NK}=0.4 \cdot k^{\prime}+106\end{array}$ & Strike-slip & $178(11 \%)$ \\
\hline$-2 \geq k^{\prime} \geq-10$ & $\begin{array}{l}188 \leq \mathrm{NK} \leq 200 \\
\mathrm{NK}=1.25 \cdot k+202.5\end{array}$ & Strike-slip / comprehensive & $114(7 \%)$ \\
\hline$-1.1 \geq k^{\prime} \geq-2$ & $\begin{array}{l}200 \leq \mathrm{NK} \leq 290 \\
\mathrm{NK}=100 \cdot k+400\end{array}$ & Comprehensive / strike-slip & $133(8 \%)$ \\
\hline$-0.5 \geq k^{\prime} \geq-1$ & $\begin{array}{l}290 \leq \mathrm{NK} \leq 300 \\
\mathrm{NK}=100 \cdot k+400\end{array}$ & Uniaxial compression & $225(14 \%)$ \\
\hline
\end{tabular}




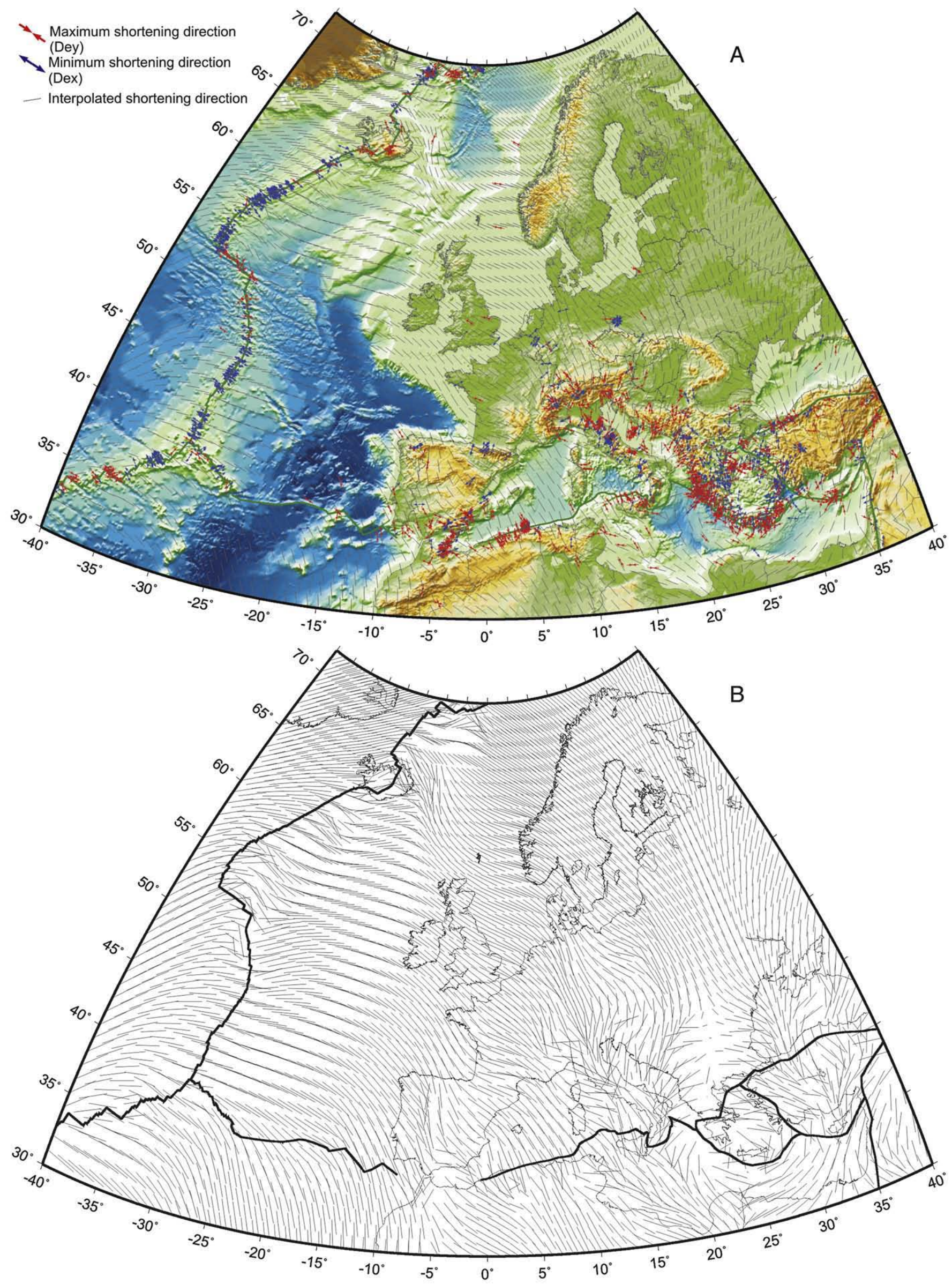

Please cite this article as: Olaiz, A.J., et al., European continuous active tectonic strain-stress map, Tectonophysics (2009), doi:10.1016/j. tecto.2008.06.023 
though these conditions may seem very restrictive, the experience verified on this kind of analysis points to on the contrary. Normally the average stress tensor determinations in the crust have a principal axis close to the vertical (Angelier, 1994). The first condition can be discussed, but it represents a much better approximation than supposing that the $\mathrm{P}$ axis of individual mechanisms coincides with the orientation of $\sigma 1$ of the stress tensor (Reches et al., 1992). The main advantage of this method is that it is a direct procedure (in contrast with the most used inversions, which are indirect methods). The method provides a value of the shape factor of the strain ellipsoid ( $k^{\prime}=e_{\mathrm{y}} / e_{\mathrm{z}}, e_{\mathrm{y}}$ maximum horizontal shortening, $e_{\mathrm{z}}$ vertical axis) and the maximum horizontal shortening trend (Dey) for every individual focal mechanism.

To map the direction of maximum horizontal shortening (Dey) we use the values obtained from the "Slip Model", except in the case of the extensional focal mechanisms on the oceanic ridges, where the interpolated axis has been Dex (maximum horizontal extension), because of the "ridge push" effect. For these vector data we obtain the $x$ - and $y$-components of each vector and then calculate the mean values for these components in 15 minute-size blocks. Then we interpolate the mean values to a 15-minute regular grid and, finally, we resample this mean value to a final $1^{\circ}$ regular grid to plot the final vectors with orientation and length according to both components (Wessel and Smith, 1998) (Fig. 4).

The value of the $k^{\prime}$ ratio varies between $+\infty$ (radial constriction) and $-\infty$ (radial stretching). We have re-sized these values to a scale between 0 and 300 (Table 1). To map the strain-stress regime, the individual $k^{\prime}$ values heterogeneously distributed, were first filtered calculating a mean value in 1515-minute-size blocks. This was made to avoid aliasing short wavelengths. Then we interpolated the mean $k^{\prime}$ value to a 15-minute regular mesh by using kriging and a linear variogram (Fig. 5) and, finally, this grid was resampled to a final 1degree regular grid.

In conclusion, we overlaid the continuous strain-stress regime and horizontal shortening direction maps over other tectonic-topography information (plate geometry and kinematics, integrated strength of the lithosphere) to discuss these results.

\section{Spatial distribution of the horizontal shortening directions}

Drawing Dey orientations to European scale (Fig. 3) turns out to be congruent with the main tectonic limits in the zone mapped, as well as with previous published maps from different approximations (Zoback, 1992; Müller et al., 1992; Heidbach et al., 2007). Nevertheless, because of the methodology used, the map resolution allows us to analyze the continuous distribution of the strain-stress regime and orientations on a whole plate scale. To analyze the variations of the horizontal stress orientations, we first describe them along the western and southern limits of the Eurasian plate (Figs. 1 and 3). Subsequently, we will describe the orientations in the intraplate areas.

Along the Mid Atlantic Ridge the Dey orientations are approximately parallel (Dex, perpendicular) to the ridge axis, except in the main transform faults (Oceanographer, Charlie-Gibbs and Jan Mayen fracture zones) where they reach $45^{\circ}$ with respect to the ridge main trend. In the Reykjanes Ridge sector, between CGTF and Iceland, the ridge presents an oblique push of approximately $75-80^{\circ}$ with regard to the ridge axis. In Iceland (Vatnajökull's zone) there are major disturbances related to reverse earthquakes and variations of $90^{\circ}$ that have been related to large volcanic eruptions (Nettles and Elkström, 1998). From the Azores Triple Junction towards the west, Dey shows a progressive rotation from $\mathrm{E}-\mathrm{W}$ to $\mathrm{WNW}$. This fact suggests that the
Terceira Ridge (Azores) is actually a "passive" extensional structure that does not generate a significant ridge push.

Between the Azores Triple Junction and the area North of Algeria the map shows a smooth rotation in the Dey orientation: from WNW to $\mathrm{N}-\mathrm{S}$, with some local variations in the $\mathrm{S}$ of the Iberian microplate, probably associated with the emplacement towards the $\mathrm{W}$ of the Alboran-Betics-Rif system (Vázquez and Vegas, 2000, De Vicente et al., 2008). Further eastwards a divergent fan of Dey orientations surrounding the Apulia-Adria system plates appears: from the North of Tunisia, Corsica and Sardinia (NW-SE), and along the eastern coast of the Adriatic Sea (NE-SW). Finally the Hellenic Arch is also characterized by a conspicuous fan of shortening trends, whereas the strike-slip systems of the Dead Sea and the North Anatolian Fault are associated with NNW-SSE shortening directions that are compatible with large scale kinematics (Kiratzi, 2002; Hofstetter et al., 2007).

Results for the Dey distribution orientations in the Eurasian Plate interior show that $\mathrm{E}-\mathrm{W}$ trends predominate in the Atlantic Ocean near the MAR (Figs. 1, 3 and 4). This notion confirms the key role of the oceanic lithosphere in the transmission of stresses, as suggested by its high integrated strength (Tesauro et al., 2007; Stuwe, 2007). In general, the horizontal stresses rotate inside Europe from an E-W trend near the Mid Atlantic Ridge, towards a NW orientation more to the north (Iceland and Fennoscandia) and to the east (western continental European platform). This general pattern has also been recognized by previous authors (Müller et al., 1992). The major variations in this general trend are located in the Pyrenees (Dey's rotation towards $\mathrm{E}-\mathrm{W}$, related to the presence of the ancient plate limit between Iberia and Eurasia), and a neutral point with convergent shortening trends (contraction) located in the $\mathrm{S}$ of the Carpathians.

\section{Spatial distribution of the strain-stress regime}

Although complex, the strain-stress regime distribution in Europe displays a good correlation with the main tectonic features and with the topography (Fig. 4). The extensional zones are clearly dominant along the MAR, except in the main transform faults (Oceanographer, Charlie-Gibbs fracture zones) and Iceland, where shortening and strike-slip zones appear. To the east of the Azores triple junction the strain regime continues to be extensional along the Gloria Fault, up to the area of the Gorringe Bank characterized by the thrusting of oceanic crust (Vázquez and Vegas, 2000), where it changes to compression. This important oceanic crustal-scale thrusting marks the beginning of the convergent limit along the contact between Eurasia and Africa in the $S$ of Europe. This convergent limit is defined by a broad band with complex geometry that goes from the SW of Iberia up to the N of Tunis, rises towards the $\mathrm{N}$ crossing Corsica and Sardinia, surrounding Italy along the Adriatic coast from the gulf of Venice up to the Hellenic Arch and Cyprus. This band shows reverse and strike-slip earthquakes, though there are also zones with extensional stresses that disconnect the continuity of the shortening zone. The complex geometry of the band and its indentation towards the $\mathrm{N}$ (Apennines and the Dinarides) is related to the presence of the Adriatic microplate, which generates compression along its border (Bada et al., 2007).

The main extensional zones in the belt of overall convergence in the Southern part of Europe are located in the Betic-Rif system, in the NE of Algeria, and in the Central Alps. These extensional areas are common in continental collisions (distributed deformation), and can also be interpreted as trans-tensional transfer systems developed inside the compressive Alpine belt of deformation. There are two large extensional zones inside the compressive belt of Southern Europe related to different processes: the Apennines and the Greece-West

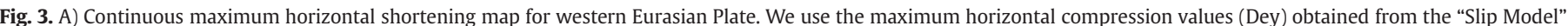

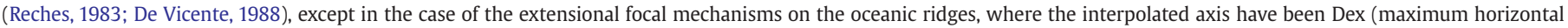

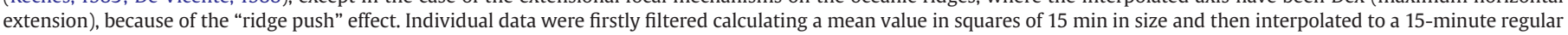
grid. B) Elongated Dey trends allow defining the shortening trajectories as well as "neutral points". See text for further explanation. 


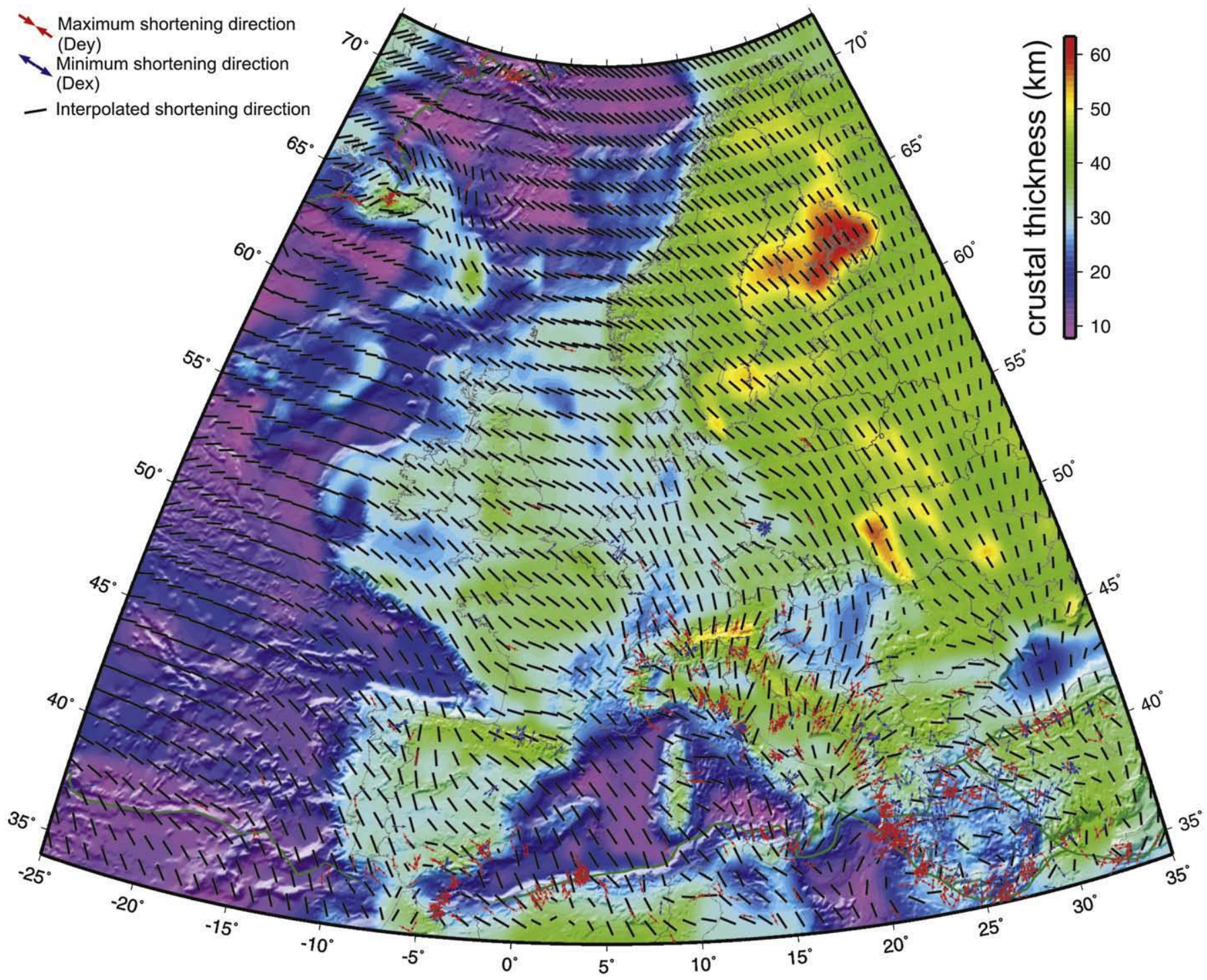

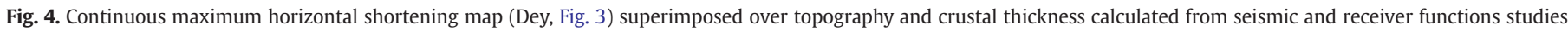
(EuCRUST-07, Tesauro et al., 2008).

Anatolian Block. In the Apennines, the stretching zone is located along the central part of the range, surrounded by wide zones in compression along the Tyrrhenian and the Adriatic Seas. This feature points to the existence of some topographic compensation within the range. In contrast, in the Aegean Sea and Greece, the extension can be related to back-arc processes of the Crete subduction system, as well as lateral extrusion of the Anatolian Block.

Inside the European plate, an extensional close to strike-slip strain regime is dominant, with well delimited areas with extensional or compressive regime. In this way, two clear intraplate extensional zones appear: the Pyrenees and Low Rhine. In the Pyrenees, stresses show an extension normal to the mean topographic trend of the chain, which appears to indicate that the activity is associated with an isostatic compensation of the topography (De Vicente et al., 2008). The extension defined in the Low Rhine is related with the development of a Cenozoic graben system extensively documented (e.g. Ziegler, 1992). The intraplate compressive nuclei are located in the Caucasus and in the west of Fennoscandia (Müller et al. 1992), which are zones of high integrated strength (Tesauro et al., 2007). The compressive area located to the West of the Baltic Shield may be related with a greater ridge push influence, or to loads related to lateral density variations in the oceanic-continental crust transition and/or to the concentration of horizontal stresses along a lithospheric flexure (Stein et al., 1989, Cloetingh et al., 1990). Other intraplate zones that present a clear strike-slip regime, are located in continental areas with high integrated strength (Tesauro et al., 2007), such as the Armorican Massif and the Variscan basement in Western Iberia. These more resistant areas allow a large quantity of elastic strain to be stored that is mainly taken up by strike-slip faulting. The main strike-slip fault corridors in Western Eurasia present a trans-tensional character in the prolongation of the Anatolian Northern Fault, in the SE of Turkey (Ecemis Fault and East Anatolian Fault) and in the Dead Sea (Jordan Fault) fault System (Fig. 4). In contrast, strike-slip faulting with a more compressive character occurs in the eastern sector of the North Anatolian Fault, The Eastern limit of the Cyprian arc and the strike-slip system of the Teisseyre-Tornquist Zone (TTZ) and the Trans-European Suture Zone (TESZ) (Jarosinski, 2005).

\section{Discussion and conclusion}

The continuous strain/stress distribution, mapped from moment tensor focal mechanisms inverted data (Dziewonski et al., 1982), enables the analysis of horizontal shortening-stretching orientations as well as the strain regime related to different tectonic environments 


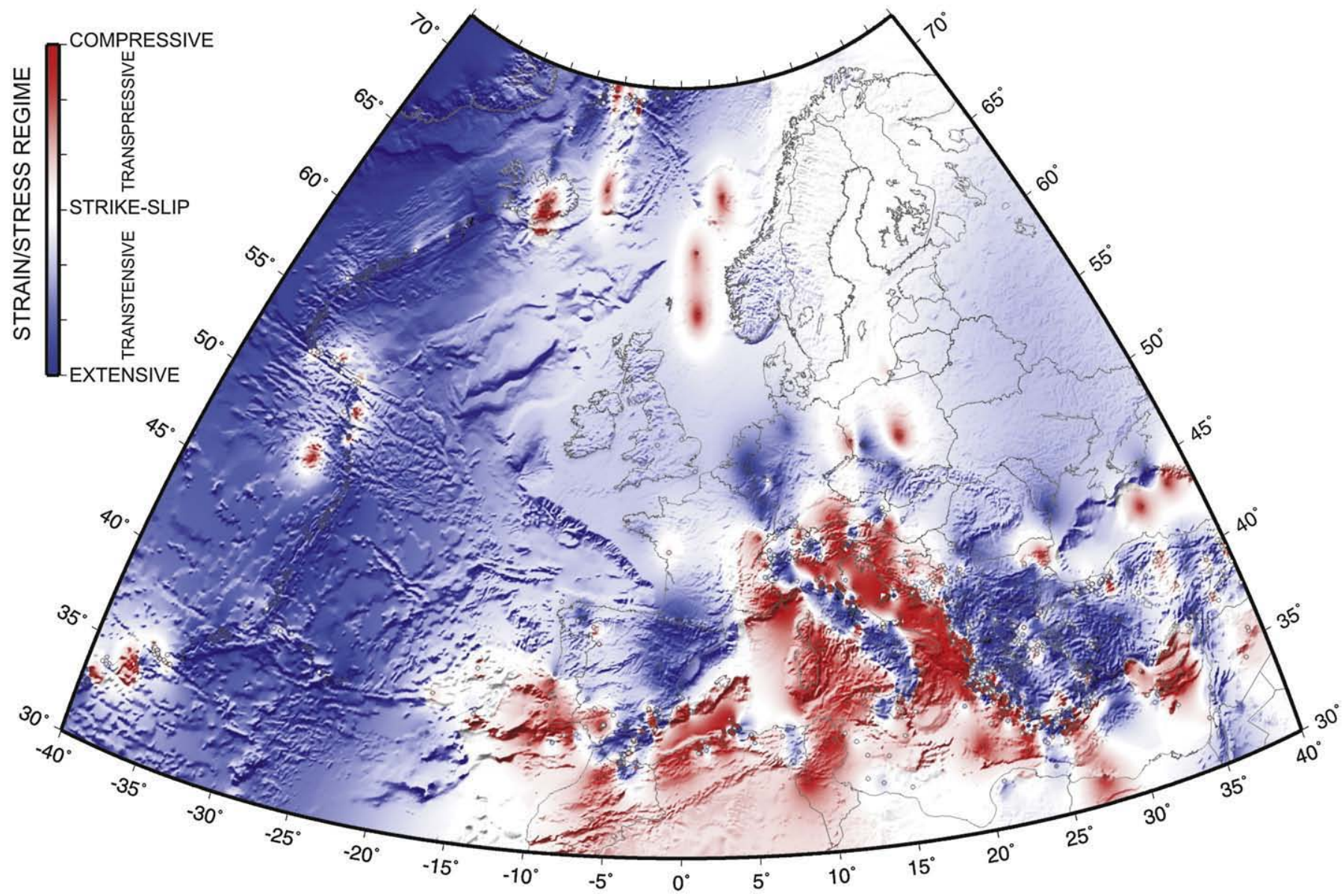

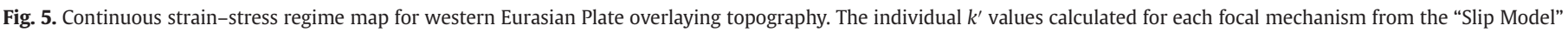

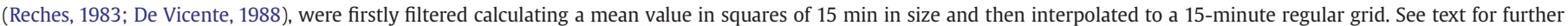
explanation.

and large scale geological heterogeneities. The methodology applied (Reches, 1983; De Vicente, 1988) allowed us to calculate the Dey values (horizontal shortening direction) and $k^{\prime}$ (strain regime) for every individual focal mechanism, which complements and provides more realistic horizontal strain/stress orientations than by just mapping the P-axis trends. Differences between horizontal trajectories calculated from the Slip Model (Dey) and P axis (i.e. Heidebach et al., 2007) reach values up to $90^{\circ}$, especially in some intraplate areas (Pyrenees, Western Alps). The Dey map reflects a large scale general pattern normal to the first-order plate limits (Mid Atlantic Ridge, and convergence belt between Eurasian and Africa Plates), with some disturbances associated with the large Transform Fault zones (Oceanographer, Charlie-Gibbs, Jan Mayen fracture zones). In the intraplate areas there are also severe perturbations in Dey trajectories that do not appear to be related to plate boundaries forces. The origin of these additional stress sources can be connected with different geological conditions: mechanical discontinuities (North Anatolia Fault, Dead Sea Fault Zone, Rhin Graben), topographic loads (Pyrenees, Apennines, Alps) or the local geometry of blocks or microplates (Adriatic microplate, Anatolian Block) (Fig. 5).

The methodology used in this study generates a data density in Western Eurasia sufficient to map the strain regime in a continuous way. This kind of continuous strain-stress mapping can be used as a boundary condition frame to analyze stress distribution over minor structures or lower scales. Another useful aspect of the new continuous strain regime map is that it allows accurate selection of the focal mechanism populations of tectonically homogeneous zones, where the more classical stress inversion procedures may be carried out, normally based on Bott's equation (Bott, 1959; Reches et al., 1992; Angelier, 1990; De Vicente et al., 2008).

The strain/stress regime presents greater complexity in its distribution than the Dey orientation regime. In general, and far from the firstorder plate limits, the strike-slip regime close to uniaxial extension prevails, included a major part of the Atlantic oceanic crust. Nevertheless, this stress regime appears to be disturbed by rifting related extensional processes parallel to Dey (Rhine Graben), or by local isostatic compensation of the topography of inactive ranges (Pyrenees). The relationships between strain/stress regime and lithospheric rheology (e.g. Tesauro et al., 2007), are not always straightforward. In general, a correlation can be observed between the most compressive strain regime, in intraplate zones with high values of integrated strength (Baltic Shield, Armorican Massif), and extensional stress regimes in zones of low lithospheric rigidity (Rhine, Pyrenees, Extensional area North of Hellenic Arch and W of Anatolian Block). At the same time, in areas located close to the first-order plate limits, the transition between shortening to stretching zones in. the strain regime map, is perpendicular to the variations in the value of integrated lithospheric strength $A$ clear example of this is observed in Western Iberia, where the Dey orientation is superimposed on the rheological crustal characteristics. This could be related to higher tectonic stress magnitudes in areas where both plates are strongly mechanically coupled.

\section{Acknowledgments}

The study was supported by Consolider Ingenio 2006 "Topo Iberia" CSD2006-00041 and the Spanish National Research Program CGL2006- 
13926-C02-01-02 "Topo Iberia Foreland". These projects are a part of the Spanish contribution to TOPO-EUROPE.

\section{References}

Andeweg, B., De Vicente, G., Cloetingh, S., Muñoz Martin, A., 1998. Local stress fields and intraplate deformation of Iberia: variations in spatial and temporal interplay of regional stress sources. Tectonophysics 305, 153-164.

Angelier, J., 1990. Inversion of field data in fault tectonics to obtain the regional stress. III. A new rapid direct inversion method by analytical means. Geophys. J. Int. 103, 363-376.

Angelier, J., 1994. Palaeostress analysis of small-scale brittle structures. In: Hancock, P. (Ed.), 'Continental deformation'. Pergamon Press, pp. 53-100. 421 pp.

Bada, G., Horváth, F., Dövényi, P., Szafián, P., Windhoffer, G., Cloetingh, S., 2007. Presentday stress field and tectonic inversion in the Panonian Basin. Glob. Planet. Change 58, 165-180.

Bott, M.H.P., 1959. The mechanism of oblique-slip faulting. Geol. Mag. 96, 109-117.

Braunmiller, J., Kradolfer, U., Baer, M., Giardini, D., 2002. Regional moment-tensor inversion in the European-Mediterranean area-initial results. Tectonophysics 356, 5-22.

Carey-Gailhardis, E., Mercier, J.L., 1992. Regional state of stress, fault kinematics and adjustments of blocks in a fractured body of rock: application to the microseismicity of the Rhine graben. J. Struct. Geol. 14, 1007-1017.

Cloetingh, S., Gradstein, F., Kooi, H., Grant, A., Kaminski, M., 1990. Plate reorganization: a cause of rapid late Neogene subsidence and sedimentation around the North Atlantic? J. Geol. Soc. (Lond.) 147, 495-506.

CSN, 1998. Proyecto SIGMA: Análisis del estado de esfuerzos tectónicos reciente y actual en la Península Ibérica. Consejo de Seguridad Nuclear. Colección Otros Documentos, 10.1998. 239 pp.

De Vicente, G. 1988. Análisis poblacional de fallas. El sector de enlace Sistema CentralCordillera Ibérica. PhD Thesis. Univ. Complutense de Madrid. 317 p.

De Vicente, G., Cloetingh, S., Muñoz-Martín, A., Olaiz, A., Stich, D., Vegas, R., GalindoZaldivar, J., Fernández-Lozano, J., 2008. Inversion of moment tensor focal mechanisms for active stresses around the microcontinent Iberia: tectonic implications. Tectonics 27. doi:10.1029/2006TC00209.

Dreger, D., Helmberger, D.V., 1993. Determination of source parameters at regional distances with three-component sparse network data. J. Geophys. Res. 98, 8107-8125.

Dziewonski, A.M., Woodhouse, J.H., 1983. An experiment in the systematic study of global seismicity: centroid moment-tensor solutions for 201 moderate and large earthquakes of 1981. J. Geophys. Res. 88, 3247-3271.

Dziewonski, A.M., Chou, T.A., Woodhouse, J.H., 1982. Determination of earthquake source parameters from waveform data for studies of global and regional seismicity. J. Geophys. Res. 86, 2825-2852.

Gölke, M., Coblentz, D., 1996. Origins of the European regional stress field. Tectonophysics 266, 11-24

Grünthal, G., Stromeyer, D., 1992. The Recent crustal stress field in Central Europe, trajectories and finite element modelling. J. Geophys. Res., B 97, 11805-11820.

Heidbach, O., Reinecker, J., Tingay, M., Müller, B., Sperner, B., Fuchs, K., Wenzel, F., 2007. Plate boundary forces are not enough: second- and third-order stress patterns highlighted in the World Stress Map database. Tectonics 26, TC6014. doi:10.1029/ 2007 TC002133.

Herraiz, M., De Vicente, G., Lindo, R., Giner, J.L., Simón, J.L., González-Casado, J.M., Vadillo, O., Rodríguez-Pascua, M.A., Cicuendez, J.I., Casas, A., Cabanas, L., Rincón, P., Cortes, A.L., Ramírez, M., Lucini, M., 2000. The recent (upper Miocene to Quaternary) and present tectonic stress distributions in the Iberian Peninsula. Tectonics 19, 762-786.

Hofstetter, R., Klinger, Y., Amrat, A., Rivera, L., Dorbath, L., 2007. Stress tensor and focal mechanisms along the Dead Sea fault and related structural elements based on seismological data. Tectonophysics 429 (3-4), 165-181.

IPSN Institute de Protection et de la Surete' Nucleaire, 1993. Seismotectonique de la France Metropolitaine dans son Cadre Geólogique et Geóphysique. Memoires Société Geólogique de France 1,1-76.
Jarosinski, M., 2005. Ongoing tectonic reactivation of the Outer Carpathians and its impact on the foreland: Results of borehole breakout measurements in Poland. Tectonophysics 410, 189-216.

Kiratzi, A.A., 2002. Stress tensor inversions along the westernmost North Anatolian Fault Zone and its continuation into the North Aegean Sea. Geophys. J. Int. 151, 360-376.

Müller, B., Zoback, M.L., Fuchs, K., Mastin, L.G., Gregersen, S., Pavoni, N., Stephansson, O., Ljunggren, C., 1992. Regional patterns of tectonic stress in Europe. J. Geophys. Res., B 97, 11783-11803.

Nettles, M., Ekström, G., 1998. Faulting mechanism of anomalous earthquakes near Bardarbunga Volcano, Iceland. J. Geophys. Res. 103 (17), 973-983.

Plenefisch, T., Bonjer, K.P., 1997. The stress field in the Rhine Graben area inferred from earthquakes focal mechanism and estimation of frictional parameters. Tectonophysics 275, 71-97.

Pondrelli, S., Morelli, A, Ekström, G., Mazza, S., Boschi, E., Dziewonski, M., 2002. European-Mediterranean regional centroid-moment tensors: 1997-2000. Phys. Earth Planet. Int. 130, 71-101.

Pondrelli, S., Morelli, A., Ekström, G., 2004. European-Mediterranean regional centroid moment tensor catalog: solutions for years 2001 and 2002. Phys. Earth Planet. Int. $145,127-147$

Randall, G.E., Ammon, C.J., Owens, T.J., 1995. Moment tensor estimation using regional seismograms from a Tibetan Plateau portable network deployment. Geophys. Res. Lett. 22, 1665-1668.

Rebaï, S., Philip, H., Taboada, A., 1992. Modern tectonic stress field in the Mediterranean region, evidence for variation in stress directions at different scales. Geophys. J. Int 110, 106-140.

Reches, Z., 1983. Faulting of rocks in three-dimensional strain fields. II Theoretica analysis. Tectonophysics $47,109-129$.

Reches, Z., Baer, G., Hatzor, Y., 1992. Constraints on the strength of the upper crust from stress inversion of fault slip data. J. Geophys. Res. 97 (B9), 12,481-12,494.

Reinecker, J., Heidbach, O., Tingay, M., Connolly, P., Müller, B., 2005. The 2005 Release of the World Stress Map. (available online at www.world-stress-map.org-stress-map.org).

Rueda, J., Mezcua, J., 2005. Near-real-time seismic moment-tensor determination in Spain. Seismol. Res. Lett. 76 (4), 455-465.

Stein, S., Cloetingh, S., Sleep, N. and Wortel, R., 1989. Passive margin earthquakes, stresses and rheology. En: Earthquakes at North Atlantic Passive Margins: Neotectonics and Postglacial Rebound, NATO ASI Serv. C. (Eds: Gregersem, S. and Basham, P.) 231-259, Kluwer Academic, Boston, EEUU.

Stich, D., Ammon, C.J., Morales, J., 2003. Moment tensor solutions for small and moderate earthquakes in the Ibero-Maghreb region. J. Geophys. Res. 108, 02JB002057.

Stuwe, K., 2007. Geodynamics of the Lithosphere, 2nd ed. Springer-Verlag, Berlin. Heidelberg, Dordrecht, 493 pp.

Tesauro, M., Kaban, M.K., Cloetingh, S., Hardebol, N.J., Beekman, F., 2007. 3D strength and gravity anomalies of the European lithosphere. Earth Planet. Sci. Lett., 263, 56-73.

Tesauro, M., Kaban, M.K., Cloetingh, S.A.P.L., 2008. EuCRUST-07: a new reference mode for the European crust. Geophys. Res. Lett. 35, LXXXXX. doi:10.1029/2007GL032244

Vázquez, J.T., Vegas, R., 2000.. Acomodación de la convergencia entre África y la Península Ibérica, Golfo de Cádiz y Mar de Alborán, a partir de del análisis de terremotos. Geogaceta 27 171-174 pp.

Wessel, P., Smith, W.H.F., 1998. New improved version of Generic Mapping Tools released. EOS Trans. AGU 79, 579.

Ziegler, P.A., 1992. North Sea Rift System. In: Ziegler, P.A. (Ed.), Geodynamics of Rifting, Volume I. Case History Studies-Rifts: Europe and Asia. Tectonophysics, vol. 208 pp. 55-75.

Zoback, M.L., 1992. First- and second-order patterns of stress in the lithosphere: the World Stress Map Project. J. Geophys. Res. 97, 11.703-11.728. 